\title{
CITIES CHALLENGES IN THE CONTEMPORARY SOCIETIES URBAN SUSTAINABILITY AND ENVIRONMENTAL ISSUES
}

\section{OS DESAFIOS DAS CIDADES NAS SOCIEDADES \\ CONTEMPORÂNEAS SUSTENTABILIDADE URBANA E QUESTÕES AMBIENTAIS}

\author{
Diogo Guedes Vidal \\ Energy, Environment and Health Research Unit, University Fernando Pessoa (UFP). Praça Nove de Abril, 349, \\ 4249-004 Porto, Portugal. Email: diogovidal@ufp.edu.pt
}

Rui Leandro Maia

Energy, Environment and Health Research Unit, University Fernando Pessoa (UFP). Praça Nove de Abril, 349, 4249-004 Porto, Portugal. Email: rlmaia@ufp.edu.pt

\section{Gisela Marta Oliveira}

Energy, Environment and Health Research Unit, University Fernando Pessoa (UFP). Praça Nove de Abril, 349, 4249-004 Porto, Portugal. Email: gisela@ufp.edu.pt

\author{
Manuela Pontes \\ Energy, Environment and Health Research Unit, University Fernando Pessoa (UFP). Praça Nove de Abril, 349, \\ 4249-004 Porto, Portugal. Email: mpontes@ufp.edu.pt
}

\section{Esmeralda Barreira}

Clínica do Pulmão, Instituto Português de Oncologia (IPO-Porto) \& Energy, Environment and Health Research Unit, University Fernando Pessoa (UFP). Praça Nove de Abril, 349, 4249-004 Porto, Portugal.

Email: merb@ufp.edu.pt

\begin{abstract}
Cities face several environmental problems related to traffic, industrialization or general intensified consumption. This article presents results from the application, at the local level, of the environmental indicator Env_WeGIx that combines several variables that translate the environment conditions of Portuguese municipalities. This composite indicator was developed based on methodological procedures used for the construction of other indicators. Preliminary results show that municipalities from Lisbon and Porto metropolitan areas are located at the bottom of the ranking due to waste production, pollutant emissions and fossil fuel consumption for transports. The municipalities located in the archipelagos, Alentejo, and Algarve regions are at the ranking top. This work's main conclusions highlight that environmental issues have direct consequences on populations' living conditions with more emphasis on urban territories, and that public policy design should take into account solutions for the environmental challenges of urban spaces. This study allowed for the development of an urban environmental sustainability indicator through a multi-scale analysis across the Portuguese territory. This indicator provides qualified knowledge for the choice and enhancement of public policies on environmental issues.
\end{abstract}

Keywords: living conditions, indicator, environmental sociology, public policies.

Resumo: As cidades deparam-se com diversos problemas ambientais relacionados com o tráfego, a industrialização ou o consumo exacerbado. Este artigo apresenta resultados da aplicação à escala local 
do indicador ambiental Env_WeGIx que congrega variáveis que traduzem as condições ambientais dos municípios. Este indicador compósito foi elaborado a exemplo da metodologia usada na construção de outros indicadores. Os resultados mostram que os municípios das Áreas Metropolitanas de Lisboa e Porto estão na base do ranking devido à produção de resíduos urbanos, às emissões de poluentes e ao consumo de combustíveis para transporte. No topo do ranking, encontram-se municípios localizados nas regiões insulares, no Alentejo e no Algarve. Este trabalho permite concluir que as questões ambientais têm consequências diretas sobre as condições de vida das populações o que se verifica com maior ênfase em territórios urbanos e que o desenho das políticas públicas destinadas a estas áreas deve contemplar soluções para os desafios ambientais. Este estudo permitiu o desenvolvimento de um indicador de sustentabilidade ambiental urbano através de uma análise multiescalar em todo o território nacional. Este indicador disponibiliza conhecimento qualificado para a escolha e aprimoramento de políticas públicas ambientais.

Palavras-chave: condições de vida, indicador, sociologia ambiental, políticas públicas.

\section{Introduction}

Urban sustainability and its related environmental dimension have been at the centre of domestic and worldwide discussion (Deakin \& Reid, 2014; European Commission, 2015; Mori \& Christodoulou, 2012; National Academies of Sciences Engineering and Medicine, 2016; Yan, Wang, Quan, Wu, \& Zhao, 2018). Economic progress and welfare driven by consumption-based lifestyles of digital and industrial established societies have not always been translated into human development - such as better living conditions, fostering healthy and productive societies, nor provided equal opportunities to enhance human capital (Graham \& White, 2016).

According to European Foundation for the Improvement of Living and Working Conditions report (1996, p. 2), sustainability could be defined as a "...striving for eternal youth...a continuous invention of new opportunities, resembling youth itself, a capacity for innovation which is a non-depletable resource, a permanent thirst for the unknown, the search for something better.". A most recent definition $(\mathrm{Wu}, 2014)$ of urban sustainability describes as an adaptive process between ecosystem services and human well-being.

Urban sustainability affects populations' living conditions and it is a very complex problem with multifactorial dimensions including the social and economic context of communities, shaped by several environmental pressure factors such as air, water or food quality (OECD, 2017; UNEP \& WHO, 2016). Human development and wellbeing are now considered so important that share national and international political goals recognized in both the United Nations Sustainable Development Goals (United Nations General Assembly, 2015) and in the European Union strategy and values, specifically in terms of Health, Environment and 
Energy issues (European Environment Agency, 2015). Sustainable development is an important issue of the modern world not only because of the urgent need of a fair distribution of wealth and the preservation of ecosystems and essential resources, but also due to the ethical evaluation criterion of sustainability, an expression of intergenerational solidarity that should be contemplated in the legal-political plan like the will of the humanity's common good. The systematic behaviour of intensive use of natural resources is accumulating negative outcomes for the environment, through pollution, that brings in negative consequences for human health and wellbeing (Reis, Morris, Fleming, Beck, Taylor, White, Depledge, Steinle, Sabel, Cowie, Hurley, Dick, Smith \& Austen, 2015). Sustainable development has to be constructed within liveable, fair, and viable societies thriving in social and environmental justice, in environmental awareness and sustainable economic progress (National Academies of Sciences Engineering and Medicine, 2016).

The global problems threatening sustainable development have special importance in urban spaces because urban metabolism systems - as the result of the cooperation among the city's governance policies, its infrastructure and its citizens - are deeply dependent on ecosystems and resource utilization (European Commission, 2015). As more people are continuously moving to cities, they tend to grow in number and population density and consequently infrastructure problems and socio-economic asymmetries tend to evolve in scale and complexity. Sustainable solutions to improve environment and life quality may require additional technological resources but most important require cooperative action among local authorities, central governments, industrial, economic and academic stakeholders, including citizens.

Sustainable solutions call for behavioural and structural governmental changes merging in an all-inclusive commitment to touch and raise awareness in every citizen. Global consciousness shared social responsibility that calls for environmental education and, consequently, the participation of informed citizens should enable to broad scope of the consequences of the human action towards nature instead of relying on governments and official institutions' willingness (Vidal, 2018). Therefore, it is of the utmost importance to empower citizens with knowledge that can create behaviours adaptable to face climate change and other global environmental consequences in order to promote sustainability (European Environment Agency, 2017; European Commission, 2015). The ground for these recommendations of wide-ranging and holistic perspectives relies on citizen's awareness, involvement and open debate both supported on proper education and rigorous information (Oliveira \& Archer, 2015). 
Within this framework, the present article contributes to public access to rigorous yet non-technical, intelligible and abridged information on populations' living conditions and on the identification of environmental problems in urban areas by comparison to rural territories, at a local level. The analysis is necessary to identify solutions for the evidence of problems aiming to reflect on the baseline conditions and impacts of the environmental dimensions of the Portuguese reality.

\section{Pathways to urban sustainability}

Since the nineties, the global changes evolving environmental degradation present such complex challenges to humanity that, as discussed by Ulrich Beck and Zygmunt Bauman, the present society may be considered a Risk Society (Beck, 1992; 1996) in part as a consequence of also being a Consumer Society (Bauman, 2000). Environmental problems are aggravated by unconscious consumeristic behaviour and by citizens' general misinformation and detachment on resource limitations and environment sustainability. Easy and cheap access to several goods and utilities conceal the depletion of natural resources required to provide basic services and invisibility endangers the planet sustainability by developing the thought that everything is spare, disposable and replaceable, contributing to a state of rapid decline of the environment (Graham \& White, 2016). In the 20th century, far-reaching advances in science and technology have contributed to a significant improvement in economic progress, better living conditions, and the growing of life expectancy (Oliveira \& Archer, 2015). However, economic driven progress did not always proceed with human development and often neglected the negative impacts on the environment, on societal organization, also globally on human living conditions, especially affected by urban lifestyle (Oliveira, Vidal \& Ferraz, 2019). Presently, around $55 \%$ of the world population lives in urban areas and this number is expected to rise over $68 \%$ by 2050 (United Nations - Department of Economic and Social Affairs - Population Division, 2018). Thus, the biggest challenge of contemporary cities is the territory management that safeguards a healthy and sustainable environment by adequate urban design planning and design and implementation of public polices at local and regional levels.

Catton and Dunlap work (Catton \& Dunlap, 1978) was an important contribution to the sociological approach to environmental issues. With NEP's development - New Ecological Paradigm - they recognized human dependency on ecosystems through an intercommunicating vision of the multiple dimensions. 
Nowadays, it is scientifically accepted that human activities and behaviour towards natural resources are inducing modifications in ecosystems' natural cycles, in some cases in irreversible manners, which will have negative impacts on human life. The concept of sustainable development as "the development that meets the needs of the present without compromising the ability of future generations to meet their own needs" (WCED, 1987, p. 15) plays a decisive role because education and information are the keys to motivate changes in individual behaviour and interaction with the planet.

The Sustainable Development Goals of United Nations 2030 Agenda (SGD) (United Nations General Assembly, 2015) was a resolution that results from the meeting that joined 198 states members and global civil society in 25th September 2015. The intergovernmental commitment is based on the principles of Resolution A/RES/66/288 "The Future that We Want", initially developed in the Rio+20 Conference realized in 2012. The 2030 Agenda establish clear goals targeted into a holistic interconnection of multiple dimensions: education, environment, health, work, public policies and human rights - social exclusion, poverty, migrations and ethnicity.

Consequently, the environmental dimension is present all over the SDGs. By 2030, the SDG Goal 11 aims that cities and generally speaking all human settlements should become inclusive, secure, resilient and sustainable spaces. To pursue this goal it is necessary to reorganize societies in several dimensions mainly at their industrial level, and above all in urban lifestyles related to daily consumption and mobility (Oliveira, Vidal \& Ferraz, 2019). Vertical urbanization, poor urban designs and lack of green spaces, among others, may define the environment quality of cities by conditioning space, light, natural atmospheric air flows (Fontes, Barros \& Manso, 2016), affecting air quality in terms that threatens human health (Barreira, Pontes, Maia, Oliveira \& Vidal, 2018). Intensive road traffic in cities is the main pollutant emitter to the atmosphere and the main cause of housing barriers due to deficient urban planning and design often aggravating poor air quality. An international comprehensive study from Anenberg and co-workers (Anenberg, Miller, Minjares, Du, Henze, Lacey, Malley, Emberson, Franco, Klimont \& Heyes, 2017) reveals that in European Union (EU-28), the number of premature deaths in cities from respiratory diseases could be reduced if measures to limit emissions from vehicles are adopted. Actual challenges in urban design plans imply a multidisciplinary approach with professionals of different fields of science and with a huge environmental educational component.

Educating the population to raise environment awareness should encourage good environment practices and "contact with nature" (Meira \& Caride, 
2001; Schmidt \& Guerra, 2013; Schmidt, Nave, \& Guerra, 2010; Schmidt, Nave, O'Riordan, \& Guerra, 2011). Scientific evidence from many projects focusing on local interventions and social participation of communities has contributed to highlight the importance of communication between municipalities (local level) and central governments (Campos, Guerra, Gomes, Schmidt, Alves, Vizinho \& Lopes, 2017; Guerra \& Schmidt, 2017; Schmidt, Ferrão, Guerra, Mourato, Alves, Baixinho \& Ferreira, 2015).

As stated by Mega and Pedersen (1998), indicators are a powerful tool in addressing the change. In this scope, it is recognized the need to develop sustainability indicators due to its potentiality in the quantification of sustainability performance. The indicators measure the living conditions in urban areas and help to identify which are the areas that most need of improvement (Phillips, 2014).

\section{Development of Env_WeGIx}

The environment and sustainability dimensions of living conditions are directly related to inclusive, safe, resilient and sustainable cities and humans' settlements. It is assumed that the conditioning factors that shape sustainable environment are all interconnected and in accordance with the UN Sustainable Development Goals. Herein, the methodology adopted to measure the Environment and Sustainability Indicator Env_WeGIx was developed as part of one project (Maia, Oliveira, Vidal, Pontes, Barreira, Guerreiro \& Estrada, 2019; Oliveira, Vidal, Viterbo \& Maia, 2020) that aims to measure living conditions at a local level in the Portuguese territory. Since the target area is Portugal $\left(92212 \mathrm{~km}^{2}\right)$ and its 308 municipalities, official statistics data sources support the WeGIx database, namely from the Portuguese national agencies: INE - the National Statistics Institute (www.ine.pt), PORDATA the Contemporary Portuguese Database (www.pordata.pt) and APA - the Portuguese Environmental Agency (www.apambiente.pt).

The Environment and Sustainability Indicator Env_WeGIx combines the following nine environmental variables (integrated in original WeGIx (Oliveira, Vidal, Viterbo \& Maia, 2020)): urban waste; domestic electricity consumption; water supplied and consumed; fuel consumption for road traffic; $\mathrm{PM}_{10}$ emissions (is particulate matter 10 micrometers or less in diameter); $\mathrm{PM}_{2.5}$ emissions $\left(\mathrm{PM}_{2.5}\right.$ is particulate matter 2.5 micrometers or less in diameter); $\mathrm{NO}_{x}$ emissions (nitrogen oxides) and area burnt by fires. The variable Urban Waste has two components depending on waste final destination: (a) Selective Urban Waste collection refers to the recycling of waste duly separated by material type; and (b), Undifferentiated Urban 


\begin{tabular}{|c|c|c|c|}
\hline Source & Selected variables & Standardization & $\begin{array}{l}\text { Impact on living } \\
\text { conditions }\end{array}$ \\
\hline PORDATA & $\begin{array}{l}\text { SSW Selective Urban Waste Collection } \\
\text { UUW } \frac{\text { Undifferentiated UrbanWaste Collection }}{\text { WSC Water Supplied/Consumed }} \\
\text { DEC Domestic Electricity Consumption }\end{array}$ & \multirow[t]{2}{*}{ Per Inhabitant } & $\begin{array}{l}+ \\
- \\
- \\
-\end{array}$ \\
\hline INE & FC Fuel Consumption for Road Traffic & & - \\
\hline APA & $\frac{\frac{\mathrm{PM}_{10} \mathrm{PM}_{10} \text { Emissions }}{\mathrm{NO}_{\mathrm{X}} \mathrm{NO}_{\mathrm{x}} \text { Emissions }}}{\underline{\mathrm{PM}_{2.5} \mathrm{PM}_{2,5} \text { Emissions }}}$ & \multirow[t]{2}{*}{ Per $\mathrm{Km}^{2}$} & $\begin{array}{l}- \\
- \\
-\end{array}$ \\
\hline PORDATA & BA Burnt Area & & - \\
\hline
\end{tabular}

Note: Database information sources may be accessed by the hyperlink provided.

Waste collection refers to the process of urban waste collection placed in the same container and its land disposal as final destination without any differentiation by type of material. The variable Burnt Area includes all types of fires, not only forest fires and therefore it is not restricted to rural zones. For decades, intense fires have been raged throughout the mainland with heavy consequences on human life and on the environment, strongly affecting living conditions. To each variable, a positive $(+)$ or negative $(-)$ character shows the impact of that variable in populations' living conditions as presented in Table 1.

Calculation of Env_WeGIx required a standardization of the variables due to different measurement units and to comply with the need to compare values relating each variable to the correspondent population or to the area of each municipality. Therefore, normalization by the resident population in each municipality was applied to all variables except for pollutants' emissions (nitrogen oxides - $\mathrm{NO}_{\mathrm{x}}$ and particulate matter $-\mathrm{PM}_{10}$ and $\mathrm{PM}_{2.5}$ ), and for the area burnt. For these three variables, normalization was referred to the geographical area of the correspondent municipality.

Normalization of variables by the resident population in a municipality i:

$$
I=\frac{v}{P}
$$

Where:

$I$ is the normalized value of a variable $\mathrm{v}$ for a municipality $\mathrm{i}$

$P$ is the resident population (number of citizens) in a municipality $\mathrm{i}$

$v$ is the value of a variable $v$ for a municipality $i$ 
Normalization of variables (pollutants emissions and area burnt) by the geographical area of a municipality i:

$$
I=\frac{v}{A}
$$

Where:

$I$ is the normalized value of a variable $\mathrm{v}$ for a municipality $\mathrm{i}$

$A$ is the geographical area $\left(\mathrm{km}^{2}\right)$ of a municipality $\mathrm{i}$

$v$, is the value of a variable $\mathrm{v}$ for a municipality $\mathrm{i}$

Then, the non-dimensioning of all the nine variables was made according to Equation 3. For every variable, the national average value is used as a reference and then, each of the nine variables of the 308 municipalities $(I)$ is converted into a non-dimensional value $(N I)$ by dividing the variable value by the national average value $(A V)$. For each of the nine individual indicators, the country value is always one: $I_{\text {Portugal }}=1$.

$$
N I=\frac{l}{A V}
$$

Where:

$I$ is the value of the indicator I for the municipality $\mathrm{i}$

$A V$ is the value of the indicator I for Portugal

$N I$ is the standard (non dimensional) value of the indicator I for the municipality i.

The present procedure allows the ranking of all municipalities above or under the reference value of one for Portugal $\left(N I_{n \rightarrow \infty}=1\right)$, for each of the nine individual indicators NI. Then, for every municipality $\mathrm{i}$, each of the Env_WeGIx indicators NI is a relative value to the national reference that is always one for each year of analysis. After all, data are standardized (normalized and nondimensional), the Env_WeGIx value for each i municipality is calculated by subtracting the aggregation of all $(n=$ 12) the negative NI variables from the non-dimensional value of the normalized value of Selective Urban Waste NSUW according to the Equation 4:

$$
E n v_{-} W e G I x=N S U W-\frac{\hat{A}_{\cdots-1} N I_{n}}{A V}
$$

For each year of analysis, Portugal always has a reference value of zero $E n v_{-} W_{e G I x}=0$ and the $E n v_{-}$WeGIx value of each municipality will float above or below the refe renced value of zero. If $E n v_{-} W e G I x_{1}>0$, then the population of that municipality experiences better living conditions than the average. On the 
other hand, if Env_WeGIx <0 it means that the municipality population lives in unfavourable living conditions compared to the national average situation.

Equation 4 translates the final form of Env_WeGIx calculation that was achieved after a series of tests to validate the selected variables of the initial model that included all nine variables.
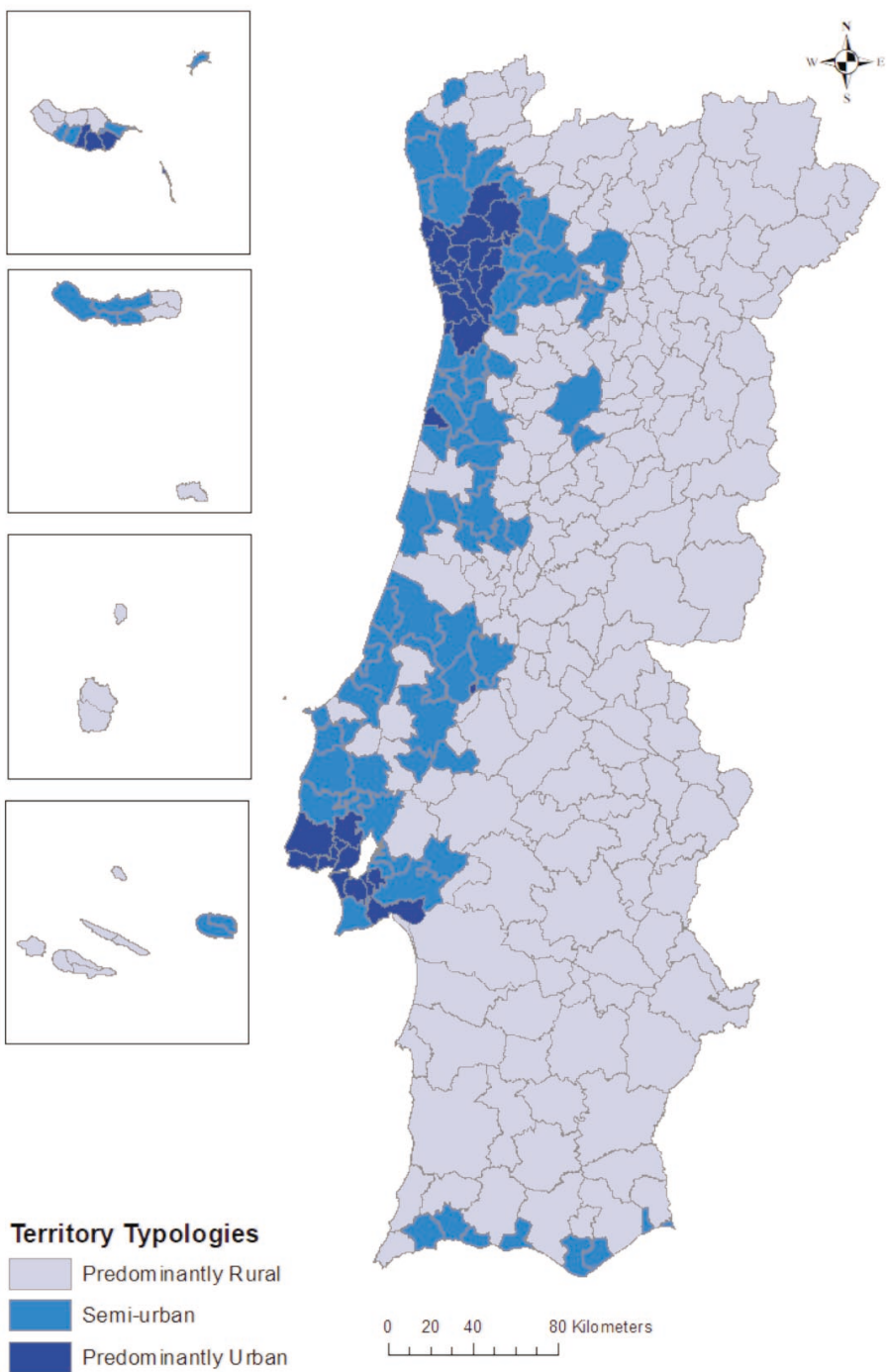

Figure 1 Territory typology of Portuguese municipalities

Source: INE, 2014. 
Data statistics treatment was made using IBM( (®) SPSS(®) Statistics vs.24.0 software. A cross-sectional study based on the years 2009 and 2015 was adopted and, in all comparative analyses, a confidence level of $95 \%$ or $99 \%(\alpha=0.05 ; \alpha=$ 0.01) was used. Data distribution was analysed by Kolmogorov-Simirnov test but normality in data distribution was not verified. Nevertheless, parametric tests were still applied because the condition $N>30$ (308 municipalities) was verified for all variables.

Spearman correlation test was applied to verify the statistic dependence among indicators. This test reveals moderate associations between some analysed indicators and weak associations between others. For the years 2009 and 2015, a comparison of the Env_WeGIx indicator scores by territory typology was conducted by a One-way ANOVA with post-hoc Tukey HSD (Honestly Significant Difference). According to INE - the National Statistics Institute, a predominantly urban territory $(\mathrm{N}=36)$ is characterized by a population density higher than 500 inhabitants $/ \mathrm{km}^{2}$; semi-urban territories $(\mathrm{N}=86)$ corresponds to regions of population density of 100 to 500 inhabitants $/ \mathrm{km}^{2}$ and at last, predominantly rural territories $(\mathrm{N}=186)$ have populations with density under 100 inhabitants $/ \mathrm{km}^{2}$ (INE, 2014). The cartographic representation of the results was performed with ArcMap TM. The representation of municipalities by territory typology is presented in Figure 1.

\section{Urban (in)sustainability in mainland Portugal: Env_WeGIx results}

Inequality marks the reality of the Portuguese municipalities regarding the environmental dimension of living conditions. Although being a small country, profound differences are found at local level, especially if related to territorial characteristics. The organization of the territories, according to their socioeconomic conditions, enables the development of daily habits of consumption that may have negative impacts in the environment and human health, directly influenced by environmental change, enhancing the risk to public health (Graham \& White, 2016).

Sedas Nunes (1964) in his well-known article about Portugal as a dual society in evolution presents a portrait of a country based on dichotomies of urban and rural territories, which corresponds to either urban or rural lifestyles. Although fifty-four years had passed, the country continues to be a dual space, predominantly rural (Vidal, Pontes, Barreira, Oliveira \& Maia, 2018) and different environmental quality between territories. If in 1964 urban territories as Porto specifically presented the higher energy consumption by inhabitant (Sedas Nunes, 1964), today the reality is a little modified. 
Table 2 One-way ANOVA with Tukey H.S.D. by territories typologies for Env_WeGIx Indicator Scores in 2009 and 2015

\begin{tabular}{|c|c|c|c|c|c|c|c|c|c|}
\hline & \multicolumn{3}{|c|}{ Descriptive statistics } & \multicolumn{4}{|c|}{ Tukey H.S.D. } & \multicolumn{2}{|c|}{ One-way ANOVA } \\
\hline & $\begin{array}{l}\text { Territory } \\
\text { typologies }\end{array}$ & $\mathrm{n}$ & Mean & Typologies & & $\begin{array}{c}\text { Mean } \\
\text { difference }\end{array}$ & $p$ & $\mathrm{~F}$ & $p$ \\
\hline \multirow{3}{*}{2009} & Predominantly & 36 & -8.5 & \multirow{3}{*}{$\begin{array}{l}\text { Predominantly } \\
\text { urban }\end{array}$} & \multirow{3}{*}{$\begin{array}{c}\text { Semi-urban } \\
\text { Predominantly } \\
\text { rural } \\
\begin{array}{c}\text { Predominantly } \\
\text { rural }\end{array}\end{array}$} & $-8.1^{*}$ & 0.00 & \multirow{3}{*}{51.8} & \multirow{3}{*}{0.00} \\
\hline & Semi-urban & 86 & -0.4 & & & $-8.4^{*}$ & 0.00 & & \\
\hline & $\begin{array}{l}\text { Predominantly } \\
\text { rural }\end{array}$ & 186 & -0.1 & & & -0.3 & 0.88 & & \\
\hline \multirow{3}{*}{2015} & $\begin{array}{l}\text { Predominantly } \\
\text { urban }\end{array}$ & 36 & -8.4 & \multirow{3}{*}{$\begin{array}{c}\text { Predominantly } \\
\text { urban }\end{array}$} & Semi-urban & $-7.9^{*}$ & 0.00 & \multirow{3}{*}{46.2} & \multirow{3}{*}{0.00} \\
\hline & Semi-urban & 86 & -0.4 & & Predominantly & $-8.3^{*}$ & 0.00 & & \\
\hline & $\begin{array}{l}\text { Predominantly } \\
\text { rural }\end{array}$ & 186 & -0.1 & & $\begin{array}{l}\text { Predominantly } \\
\text { rural }\end{array}$ & -0.3 & 0.86 & & \\
\hline
\end{tabular}

* Correlation is significant at the 0.05 level

Table 2 presents the results of One-way ANOVA with Tukey H.S.D test for the Env_WeGIx indicator for the two years analyzed: 2009 and 2015.

The results of this test put in evidence that between 2009 and 2015 citizens did not experience an improvement of the environmental conditions. On the other hand, and in contrast with other territories typology (semi-urban and predominantly rural) the predominantly urban territories present worst performances in the Env_WeGIx indicator, in accordance with a recent study (Maia, Vidal, \& Oliveira, 2018). In fact, the mean differences are only statistically significant when comparing predominantly urban territories with semi-urban or with predominantly rural territories $(p<.001)$. The comparison of semi-urban territories with predominantly rural territories is not statistically significant $(\mathrm{p}>0.05)$

Table 3 presents the municipalities ranking of the highest and lowest Env_WeGIx scores. This table presents also the ranking position variation from 2009 to 2015 and which municipality had the highest positive or negative variation.

According to Table 3 the highest positive variations from 2009 to 2015 correspond to the municipalities of "Vieira do Minho" (3.45) and "Angra do Heroísmo" (2.08). This reason may be related to the improvement of waste collected in a selective manner to be recycled and to the decrease of water consumption. In contrast, the municipalities that exhibit the highest negative variation are "Entroncamento" (-24.71) and "Amadora" (-13.06). The reasons behind the environmental degradation of these two municipalities are related to the increase 
Table 3 Municipalities with the fifteen Env_WeGIx Indicator highest and lowest scores in 2015 and their correspondent values in 2009 and period variation

\begin{tabular}{|c|c|c|c|c|c|c|c|}
\hline & \multirow[b]{2}{*}{ Municipality } & \multicolumn{2}{|c|}{2015} & \multicolumn{2}{|c|}{2009} & \multicolumn{2}{|c|}{ Variation } \\
\hline & & $\begin{array}{l}\text { Indicator } \\
\text { value }\end{array}$ & Rank & $\begin{array}{l}\text { Indicator } \\
\text { value }\end{array}$ & Rank & Value & Rank \\
\hline $\begin{array}{l}\text { Highest } \\
\text { scores }\end{array}$ & \begin{tabular}{l} 
Vila do Bispo \\
Lagoa \\
Angra do Heroísmo \\
Portimão \\
Lagos \\
Vieira do Minho \\
Albufeira \\
Alvito \\
Aljezur \\
Loulé \\
Terras de Bouro \\
Vila da Praia da Vitória \\
Cuba \\
Porto Moniz \\
Lajes das Flores \\
\multicolumn{2}{c}{ Reference Value }
\end{tabular} & $\begin{array}{r}3.12 \\
2.73 \\
2.35 \\
2.34 \\
2.34 \\
2.27 \\
1.92 \\
1.91 \\
1.72 \\
1.57 \\
1.53 \\
1.43 \\
1.31 \\
1.29 \\
1.07 \\
0.0\end{array}$ & $\begin{array}{r}1 \\
2 \\
3 \\
4 \\
5 \\
6 \\
7 \\
8 \\
9 \\
10 \\
11 \\
12 \\
13 \\
14 \\
15\end{array}$ & $\begin{array}{r}2.37 \\
2.05 \\
0.27 \\
2.38 \\
2.52 \\
-1.18 \\
1.4 \\
1.04 \\
2.15 \\
1.70 \\
-0.51 \\
0.12 \\
0.83 \\
0.62 \\
-0.93 \\
0.0\end{array}$ & $\begin{array}{r}3 \\
6 \\
63 \\
2 \\
1 \\
261 \\
16 \\
20 \\
5 \\
13 \\
210 \\
78 \\
23 \\
34 \\
248\end{array}$ & $\begin{array}{r}0.75 \\
0.68 \\
2.08 \\
-0.04 \\
-0.18 \\
3.45 \\
0.45 \\
0.87 \\
-0.43 \\
-0.13 \\
2.04 \\
1.31 \\
0.48 \\
0.67 \\
2.00\end{array}$ & $\begin{array}{r}7 \\
8 \\
2 \\
13 \\
15 \\
1 \\
11 \\
6 \\
12 \\
14 \\
3 \\
5 \\
10 \\
9 \\
4\end{array}$ \\
\hline $\begin{array}{l}\text { Lowest } \\
\text { scores }\end{array}$ & \begin{tabular}{l} 
Ílhavo \\
Almada \\
Vizela \\
Vila Nova de Cerveira \\
Sines \\
Espinho \\
Estarreja \\
Oeiras \\
Lisboa \\
Odivelas \\
Porto \\
Matosinhos \\
Entroncamento \\
São João da Madeira \\
Amadora \\
\multicolumn{1}{c}{ Reference Value }
\end{tabular} & $\begin{array}{r}-4,54 \\
-5,35 \\
-5.61 \\
-6.08 \\
-7.50 \\
-8.45 \\
-9.34 \\
-10.44 \\
-15.32 \\
-24.93 \\
-25.45 \\
-27.17 \\
-38.47 \\
-43.80 \\
-57.83 \\
0.0\end{array}$ & $\begin{array}{l}294 \\
295 \\
296 \\
297 \\
298 \\
299 \\
300 \\
301 \\
302 \\
303 \\
304 \\
305 \\
306 \\
307 \\
308 \\
\end{array}$ & $\begin{array}{r}-1,41 \\
-4,82 \\
-5.92 \\
0.07 \\
-6.77 \\
-11.29 \\
-2.29 \\
-11.99 \\
-13.54 \\
-29.24 \\
-27.94 \\
-16.88 \\
-13.76 \\
-56.51 \\
-44.77 \\
0.0\end{array}$ & $\begin{array}{r}269 \\
293 \\
295 \\
84 \\
296 \\
297 \\
284 \\
299 \\
300 \\
306 \\
305 \\
303 \\
301 \\
308 \\
307\end{array}$ & $\begin{array}{r}-3,13 \\
-0,53 \\
0.31 \\
-6.15 \\
-0.73 \\
2.84 \\
-7.05 \\
1.55 \\
-1.78 \\
4.31 \\
2.49 \\
-10.29 \\
-24.71 \\
12.71 \\
-13.06\end{array}$ & $\begin{array}{r}10 \\
7 \\
6 \\
11 \\
8 \\
3 \\
12 \\
5 \\
9 \\
2 \\
4 \\
13 \\
15 \\
1 \\
14\end{array}$ \\
\hline
\end{tabular}

of fuel consumption for road transport and the consequent increase of pollutant emissions $\left(\mathrm{PM}_{10}, \mathrm{PM}_{2.5}\right.$ and $\left.\mathrm{NO}_{\mathrm{x}}\right)$. These results are according to the findings of a study concluding that vehicles with diesel combustion engines are the main reason for pollutant emissions in Europe (Anenberg, Miller, Minjares, Du, Henze, Lacey, Malley, Emberson, Franco, Klimont \& Heyes, 2017).

The relations between the variables that compose the Env_WeGI $x$ are presented in Table 4 with Spearman correlations results.

The strongest positive correlation is between the $\mathrm{PM}_{10}$ and $\mathrm{PM}_{2.5}$ and the NOx pollutant emissions $\left(r_{s}=0.948 ; p<0.01\right)$. Another positive but moderate correlations was found between "Domestic Electricity Consumption" and "Undifferentiated Urban Waste Collection" $\left(\mathrm{r}_{\mathrm{s}}=0.602 ; p<0.01\right)$ and between "Domestic Electricity Consumption" and "Water Supplied/Consumed" 


\begin{tabular}{lcccccccc}
\hline & WSC & UUW & SUW & FC & $\mathrm{NO}_{x}$ & $\begin{array}{c}\mathrm{PM}_{10} \& \\
\mathrm{PM}_{2.5}\end{array}$ & DEC & BA \\
\hline WSC & 1 & & & & & & & \\
UUW & $0.389^{* *}$ & 1 & & & & & & \\
SUW & $0.230^{* *}$ & $0.358^{* *}$ & 1 & & & & & \\
FC & 0.106 & 0.094 & $0.169^{* *}$ & 1 & & & & \\
NOx & $-0.217^{* *}$ & -0.048 & $0.186^{* *}$ & $0.131^{*}$ & 1 & & & \\
PM 10 \& PM $_{2.5}$ & $-0.175^{* *}$ & -0.062 & $0.202^{* *}$ & $0.117^{*}$ & $0.948^{* *}$ & 1 & 1 & \\
DEC & $0.533^{* *}$ & $0.602^{* *}$ & $0.415^{* *}$ & $0.177^{* *}$ & $-0.209^{* *}$ & $-0.191^{* *}$ & 1 \\
BA & -0.085 & $-0.347^{* *}$ & $-0.235^{* *}$ & $-0.145^{*}$ & -0.025 & 0.052 & $-0.212^{* *}$ & 1 \\
\hline
\end{tabular}

${ }^{*}$ Correlation is significant at the 0.05 level ${ }^{* *}$ Correlation is significant at the 0.01 level

$\left(r_{s}=0.533 ; p<0.01\right)$. These relations may be explained by contemporary society's general consumeristic behaviour, especially related to water and energy daily use habits and waste production. Due to the concentrated population, urban spaces have the highest waste production and its management continues to be a challenge.

Figure 2 and Figure 3 present the cartographic representation of the totality of the Env-WeGIx results in the years 2009 and 2015, respectively. These findings provide a clear reading of the Portuguese reality and illustrate the degradation of the living conditions at the environmental level. The comparison of the two years of analysis results (Figure 1 and Figure 2) shows that municipalities and their citizens have not experienced, in general, an improvement of environmental conditions.

Finally, a fact worth to mention is that, in both years of analysis, the municipalities with lowest scores have at least one of the following conditions: (i) they are located in coastal regions, in particular in the outskirts of "Lisboa" or "Porto" metropolitan areas, or (ii) they include industrial hubs, as evidenced in the municipalities of "Sines" (coast of "Alentejo"), in the south margin of Lisboa Metropolitan Area and some other municipalities at the littoral centre of Portugal mainland. These results are in accordance with an exhaustive characterization (Oliveira, 2016) of the country industrial sources of greenhouse gases and pollutant emissions, reporting the municipalities of "Setúbal" (south margin of Lisbon metropolitan area), "Figueira da Foz" and "Aveiro" (both in coastal centre of mainland Portugal) as the territories with the highest emissions of GHG and pollutants. Sines on the southern coast ("Alentejo") is the municipality with the biggest electricity consumption due to the high concentration of industrial facilities including a coal power plant and an oil refinery. 

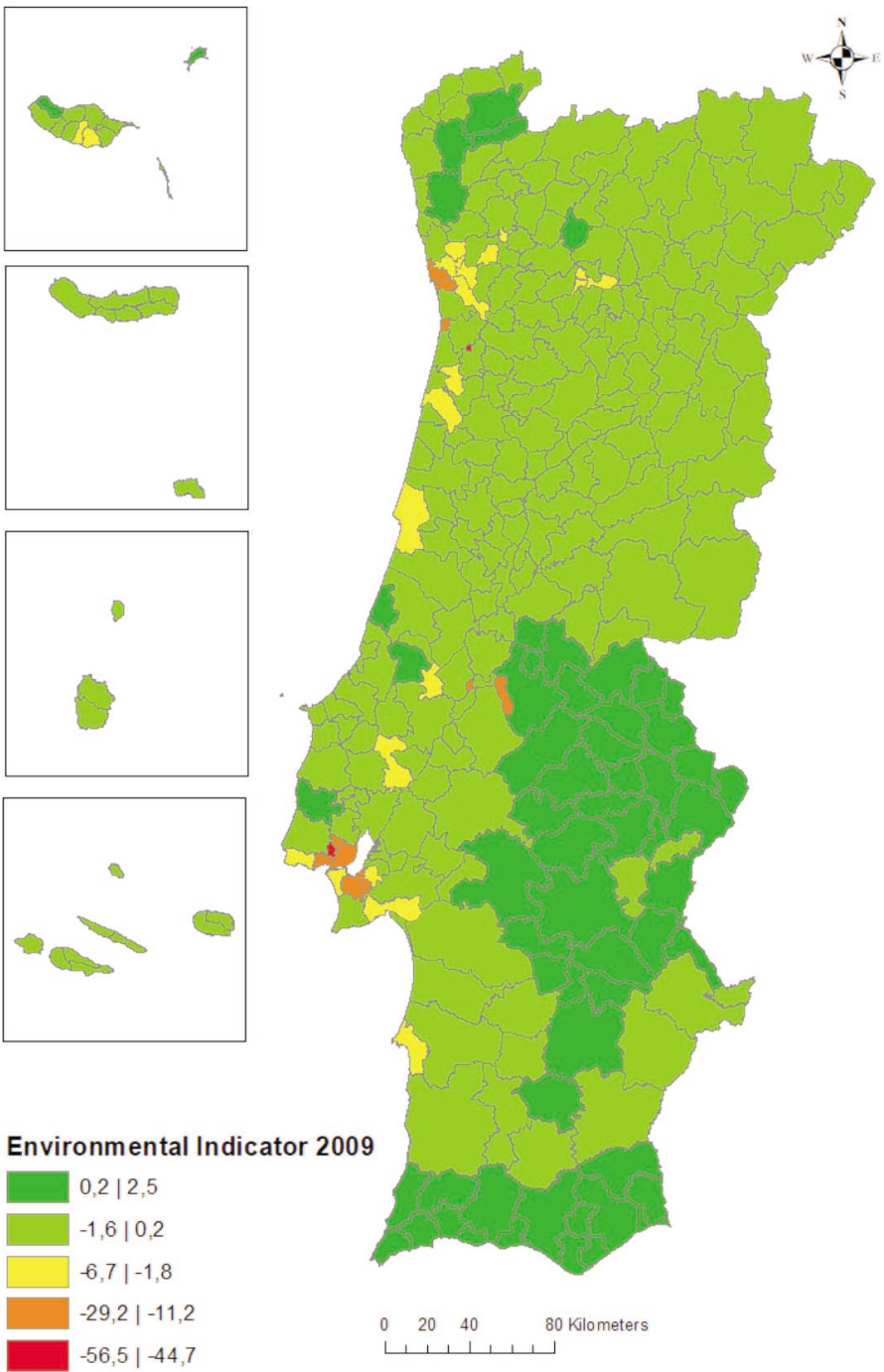

Figure 2
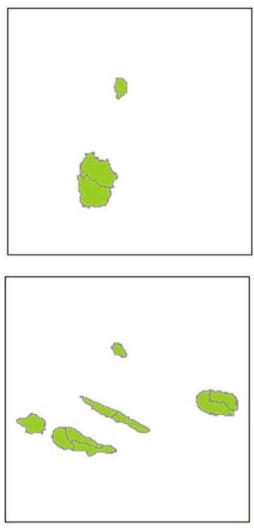

\section{Environmental Indicator 2009}

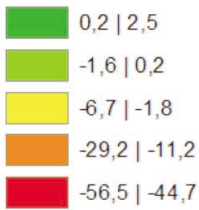



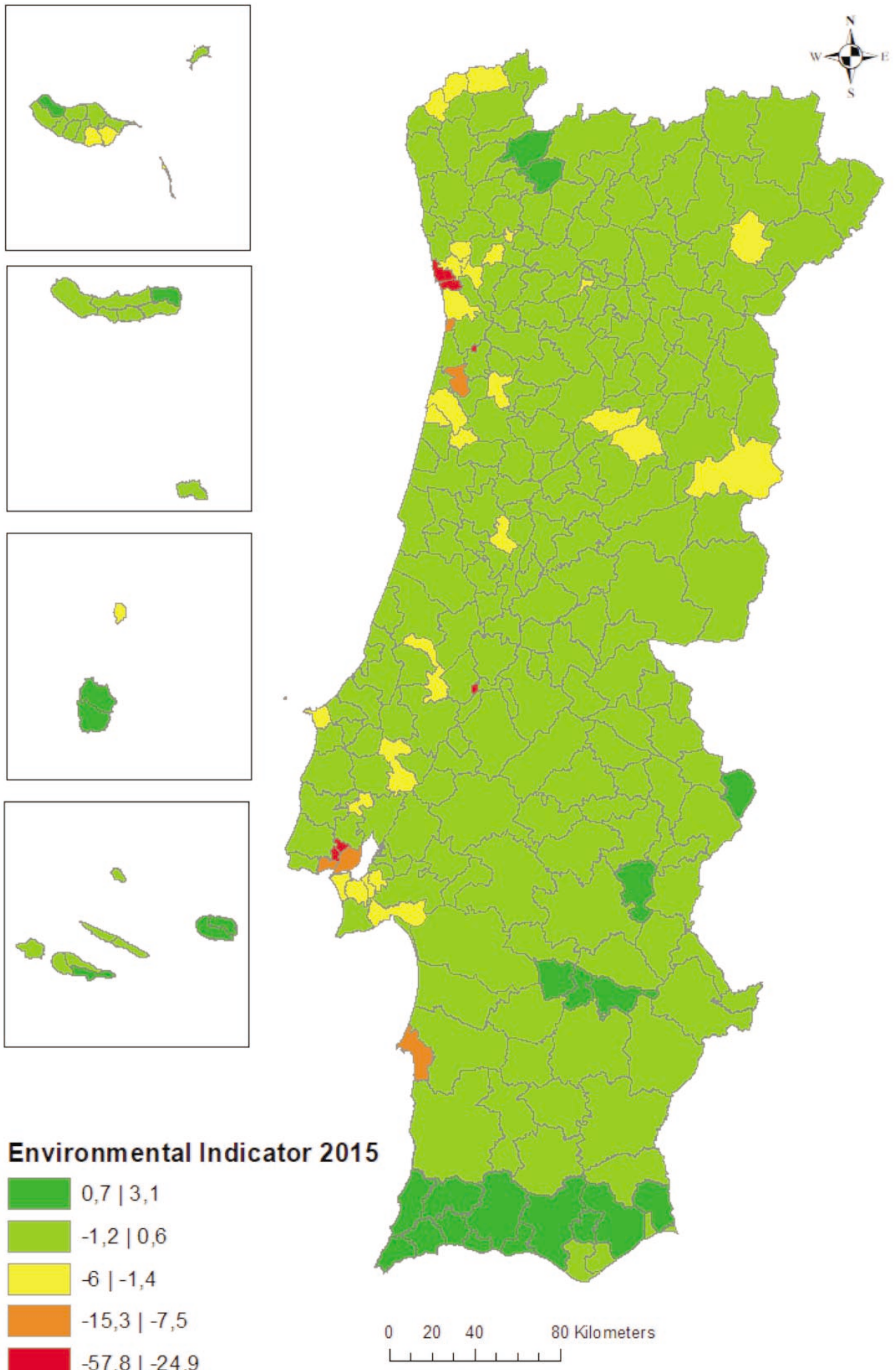

Figure 3

Env_WeGIx indicator scores for Portuguese municipalities in 2015 


\section{Conclusions}

The direct relation between environmental pollution and impacts on human health should be a main concern for governments and object of specific and urgent policies. The design of public policies should consider the environmental, economic and social dimensions in a holistic manner that put human health and living conditions as core issues. Cities, territories, and their social, economic, cultural, and political construction processes have natural specificities that should be considered in the elaboration of public policies, mainly to explore and enhance sustainability factors and attractiveness for citizens. The contemporary consumeristic behaviour, namely related to energy and natural resources, results in negative impacts on environment. There is an urgent need to solve the conflict between human and economic development. This evidence brings to the centre of discussion the principle of Sustainable Development which corresponds to a framework that enables to suppressing our demands without compromising the needs of future generations (United Nations - World Commission on Environment and Development, 1987).

The proposed model for Env_WeGIx has exposed the risks of the restraints on data scarcity in number and time which explains why the availability of official statistical data and its restraints due to data scarcity in number and in time which explains why the index was only applied for the isolated years of 2009 and 2015. This time gap is a limitation due to the absence of official data regarding pollutant emissions that are parameters considered highly relevant to properly evaluate environmental conditions. SDGs require strengthening of statistical capacities (Guerra \& Brito Lourenço, 2018), as information technologies are developing fast and procedures become standardized at the European Union level, the readiness of official reliable data shall increase. In the future, the calculation of Env_WeGIx on an annual base for a timeline would allow following the evolution of environmental conditions and their impact on the populations' living conditions providing evidence to advise on public policies implementation at the local level for each municipality. Besides being built on reliable data, other Env_WeGIx strengths relate to its simplicity: it provides a number that may readily be understood, compared with the country average, and creates easy to read and comprehensible maps. Although Env_WeGIx was designed for Portugal and in the framework of the UN 2030 Agenda for theSDGs, the concept of the present index model is adaptable to the reality of other countries and adjustable to take into account countries' characteristics and specificities.

The achievement of this study was reached with the development of an urban environmental sustainability indicator through a multi-scale analysis across the 
Portuguese territory to provide qualified knowledge for the choice and enhancement of public policies on environmental issues.

\section{Acknowledgments}

WeGIx is a research project of FP-ENAS - UFP Energy, Environment and Health Research Unit funded by FCT - Fundação para a Ciência e a Tecnologia, I.P. through project UID/MULTI/4546/2019.

\section{References}

Anenberg, S. C., Miller, J., Minjares, R., Du, L., Henze, D. K., Lacey, F., Malley, C. S., Emberson, L., Franco, V., Klimont, Z., \& Heyes, C. (2017). Impacts and mitigation of excess diesel-related NOx emissions in 11 major vehicle markets. Nature, 545(7655), 467-471. DOI: 10.1038/nature22086

Barreira, E., Pontes, M., Maia, R. L., Oliveira, G. M., \& Vidal, D. G. (2018). Cancro do pulmão e poluição: Um estudo transversal. Onco.News, (37), 14-19. DOI: $10.31877 /$ on.2018.37.02

Bauman, Z. (2000). Liquid modernity. Malden: Polity Press.

Beck, U. (1992). How modern is modern society?. Theory, Culture \& Society, 9(2), 163-169. DOI: $10.1177 / 026327692009002011$

Beck, U. (1996). World risk society as cosmopolitan society? Ecological questions in a framework of manufactured uncertainties. Theory, Culture \& Society, 13(4), 1-32. DOI: $10.1177 / 0263276496013004001$

Campos, I., Guerra, J., Gomes, J. F., Schmidt, L., Alves, F., Vizinho, A., \& Lopes, G. P. (2017). Understanding climate change policy and action in Portuguese municipalities: A survey. Land Use Policy, 62, 68-78. DOI: 10.1016/j.landusepol.2016.12.015

Catton, W. R. J., \& Dunlap, R. E. (1978). Paradigms, theories, and the primacy of the hep-nep distinction. The American Sociologist, 13(4), 256-259.

Deakin, M., \& Reid, A. (2014). Sustainable urban development: Use of the environmental assessment methods. Sustainable Cities and Society, 10, 39-48. DOI: 10.1016/j.scs.2013.04.002

European Commission. (2015). Indicators for sustainable cities. In-depth report. Science for Report, (12). Retrieved from http://ec.europa.eu/environment/integration/research/newsalert/pdf/indicator s_for_sustainable_cities_IR12_en.pdf

European Environment Agency (EEA). (2015). A Europe to thrive in - Environment, health and well-being. Copenhagen. Retrieved from https://www.eea.europa.eu/articles/a-europe-to-thrive-in 
https://www.eea.europa.eu/downloads/64d3d31114b3404eab4c3590b11f4ebf/14296212 00/a-europe-to-thrive-in.pdf

European Environment Agency (EEA). (2017). Climate change, impacts and vulnerability in Europe 2016: An indicator-based report (EEA Report, No 1/2017). Luxembourg: Publications Office of the European Union. Retrieved from http://www.eea.europa.eu/publications/climate-change-impacts-and-vulnerabili ty-2016

European Foundation for the Improvement of Living and Working Conditions. (1996). Intermediate cities in search of sustainability. Dublin: European Foundation for the Improvement of Living and Working Conditions. Retrieved from https:/ / publications.europa.eu/en/publication-detail/-/publication/b57a301a-7e ef-460d-b32e-92adc7d5683c

Fontes, T., Barros, N., \& Manso, C. (2016). Impact of air pollution in urban areas: Guidelines to buy or rent a more healthful home. Paper presented at the International Conference in Urban Risks, Lisbon. Retrieved from http://www.ceru-europa.pt/icur2016/ICUR2016_Proceedings.pdf

Graham, H., \& White, P. C. L. (2016). Social determinants and lifestyles: Integrating environmental and public health perspectives. Public Health, 141, 270-278. DOI: 10.1016/j.puhe.2016.09.019

Guerra, J., \& Brito Lourenço, L. (2018). The 2030 agenda: Trends of transition toward sustainability. Changing societies: Legacies and challenges. the diverse worlds of sustainability, 55-87. DOI: 10.31447/ics9789726715054.02

Guerra, J., \& Schmidt, L. (2017). Capacitação local e processos adaptativos. O lugar dos professores no projeto ClimadaPT.Local. Ambientalmente Sustentable, 1(23-24), 63-73.

Instituto Nacional de Estatística I.P. (INE). (2014). Tipologia de áreas urbanas 2014 Relatório técnico. Lisbon: INE. Retrieved from https://www.ine.pt/xportal/xmain?xpid=INE\&xpgid=ine_cont_inst\&INST=6251 $013 \& x$ lang $=$ en

Maia, R. L., Oliveira, G. M., Vidal, D. G., Pontes, M., Barreira, E., Guerreiro, M. J., \& Estrada, R. (2019, in press). Desafios e oportunidades do desenvolvimento sustentável local: O projeto WeGIx como proposto de monitorização. In E. Araújo, R. Ribeiro, \& M. Silva (Eds.), Sustentabilidade e descarbonização - Para um guia prático. Braga: CECS - Centro de Estudos de Comunicação e Sociedade.

Maia, R. L., Vidal, D. G., \& Oliveira, G. M. (2018, in press). Ambiente e saúde: Uma leitura comparada a partir das estatísticas dos meios rurais e urbanos. A Obra Nasce: Revista de Arquitectura Da Universidade Fernando Pessoa, (13).

Mega, V., \& Pedersen, J. (1998). Urban sustainability indicators. Dublin: European Foundation for the Improvement of Living and Working Conditions.

Meira, P., \& Caride, J. (2001). Educación ambiental y desarrollo humano. Barcelona: Ariel. Mori, K., \& Christodoulou, A. (2012). Review of sustainability indices and indicators: Towards a new city sustainability index (CSI). Environmental Impact Assessment Review, 32(1), 94-106. DOI: 10.1016/j.eiar.2011.06.001 
National Academies of Sciences Engineering and Medicine. (2016). Pathways to urban sustainability: Challenges and opportunities for the United States. Washington, DC: The National Academies Press.

OECD. (2017). How's life? 2017: Measuring well-being. Paris: OECD Publishing.

Oliveira, G. M. (2016). Roteiro tecnológico (roadmap) da captação, utilização e armazenamento de dióxido de carbono (CCUS) em Portugal (Doctoral thesis). Universidade Fernando Pessoa, Portugal. Retrieved from https://bdigital.ufp.pt/handle/10284/5636

Oliveira, G. M., \& Archer, A. B. (2015). Ambiente e desenvolvimento sustentável: Educação para a ética e cidadania. Sensos IO, 5(2), 185-200.

Oliveira, G. M., Vidal, D. G., \& Ferraz, M. P. (2019, in press). Urban lifestyles and consumption patterns. In Sustainable cities and communities. Encyclopedia of the UN sustainable development goals. Cham: Springer. DOI: 10.1007/978-3-319-71061-7_54-1

Oliveira, G. M., Vidal, D. G., Viterbo, L. M. F., \& Maia, R. L. (2020). Measuring the implementation of sustainable development goals at a local level: the WeGIx Index. In W. Leal Filho, F. Frankenberger, \& U. Tortato (Eds.), Universities and sustainable communities: Meeting the goals of the Agenda 2030 World Sustainability Series (pp. 215-245). Cham: Springer International Publishing.

DOI: 10.1007/978-3-030-30306-8_13

Phillips, R. (2014). Urban sustainability indicators. In A. C. Michalos (Ed.), Encyclopedia of quality of life and well-being research (pp. 6869-6872). Dordrecht: Springer Netherlands.DOI: 10.1007/978-94-007-0753-5_3129

Reis, S., Morris, G., Fleming, L. E., Beck, S., Taylor, T., White, M., Depledge, M. S., Steinle, S., Sabel, C. E., Cowie, H., Hurley, F., Dick, J., Smith, R. I., \& Austen, M. (2015). Integrating health and environmental impact analysis. Public Health, 129(10), 1383-1389. DOI: 10.1016/j.puhe.2013.07.006

Schmidt, L., Ferrão, J., Guerra, J., Mourato, J. M., Alves, A. F., Baixinho, A., \& Ferreira, J. G. (2015). Adaptação às alterações climáticas nos municípios: Um processo de aprendizagem social. In J. Ferrão, \& A. Horta (Eds.), Ambiente, território e sociedade. Novas agendas de investigação (pp. 125-131). Lisboa: Imprensa de Ciências Sociais.

Schmidt, L., \& Guerra, J. (2013). Do ambiente ao desenvolvimento sustentável: Contextos e protagonistas da educação ambiental em Portugal. Revista Lusófona de Educação, 25, 193-211.

Schmidt, L., Nave, J. G., \& Guerra, J. (2010). A educação ambiental: Balanço e perspectivas para uma agenda mais sustentável. Lisboa: Imprensa de Ciências Sociais.

Schmidt, L., Nave, J. G., O’Riordan, T., \& Guerra, J. (2011). Trends and dilemmas facing environmental education in Portugal: From environmental problem assessment to citizenship involvement. Journal of Environmental Policy E Planning, 13(2), 159-177. DOI: 10.1080/1523908X.2011.576167

Sedas Nunes, A. (1964). Portugal: Sociedade dualista em evolução. Análise Social, II(7-8), 407-462. 
United Nations - Department of Economic and Social Affairs - Population Division. (2018). World urbanization prospects: The 2018 revision. New York: United Nations. Retrieved from https://esa.un.org/unpd/wup/Download/ https://www.un.org/development/desa/publications/2018-revision-of-world-ur banization-prospects.html

United Nations Environment Programme (UNEP), \& World Health Organization (WHO). (2016). Healthy environment, healthy people. Retrieved from https://www.unenvironment.org/news-and-stories/story/healthy-environmenthealthy-people

United Nations General Assembly. (2015). Transforming our world: The 2030 Agenda for Sustainable Development - Resolution adopted by the UN General Assembly on 25 September 2015. Retrieved from http://www.un.org/en/development/desa/population/migration/generalassem bly/docs/globalcompact/A_RES_70_1_E.pdf

United Nations - World Commission on Environment and Development. (1987). Report of the World Commission on Environment and Development: Our common future. United Nations. Retrieved from http://www.un-documents.net/a42-427.htm.

Vidal, D. G. (2018). Ecoconsciencialização das cidades: Uma emergência global. Plataforma Barómetro Social, 2. Retrieved from https://bdigital.ufp.pt/handle/10284/7651

Vidal, D. G., Pontes, M., Barreira, E., Oliveira, G. M., \& Maia, R. L. (2018). Differential mortality and inequalities in health services access in mainland Portugal. Finisterra - Revista Portuguesa de Geografia, 53(109), 53-70. DOI: 10.18055/Finis14118

World Commission on Environment and Development (WCED). (1987). Our common future. Retrieved from

Wu, J. (2014). Urban ecology and sustainability: The state-of-the-science and future directions. Landscape and Urban Planning, 125, 209-221. DOI: 10.1016/j.landurbplan.2014.01.018

Yan, Y., Wang, C., Quan, Y., Wu, G., \& Zhao, J. (2018). Urban sustainable development efficiency towards the balance between nature and human well-being: Connotation, measurement, and assessment. Journal of Cleaner Production, 178, 67-75. DOI: 10.1016/j.jclepro.2018.01.013

Data de submissão: 24/04/2019 | Data de aceitação: 05/07/2019 